\title{
POTENSI SUMBERDAYA, TIPE FLUIDA DAN SISTIM PANAS BUMI IE SU'UM - MASJID RAYA, KABUPATEN ACEH BESAR
}

\author{
Oleh: \\ Herry Sundhoro \\ Pokja Panas Bumi, Pusat Sumber Daya Geologi (PMG)
}

\section{S ARI}

Paper ini merupakan hasil awal pekerjaan panas bumi yang dilakukan secara sistimatik, dalam rangka pemanfaatan energi panas bumi bagi tenaga listrik di Kabupaten Aceh Besar.

Pekerjaan dimaksudkan untuk mengetahui potensi sumberdaya, tipe fluida dan sistim panas bumi sebagai pegangan dalam menentukan langkah eksplorasi lanjut.

Daerah Ie Su'um terletak di ujung baratlaut daratan P. Sumatera. Manifestasi panas berada di antara 2 (dua) patahan Krueng Raya, arah barat baratlaut-selatan tenggara, Gejala permukaan sebagai idikasi potensi panas di kedalaman, berupa munculan airpanas bersuhu 86 dan $86,4^{\circ} \mathrm{C}$ di elevasi $82 \mathrm{~m}$ dpl.

Karakteristik geologi dan geokimia menunjukkan airpanas tersebut bertipe klorida, sistim up-flow, luas daerah prospek $\pm 0,5 \mathrm{~km}^{2}$, ditentukan berdasarkan anomali konsentrasi mencuri tanah dan $\mathrm{CO}_{2}$ udara tanah nilai tinggi. Estimasi sumberdaya (hipotetis) \pm 12 Mwe (untuk daerah $0,5 \mathrm{~km}^{2}$ ).

\section{LATAR BELAKANG}

Berdasarkan kondisi geologinya daerah Kabupaten Aceh Besar banyak memiliki sumber energi alternatif panas bumi.

Di dalam memenuhi konsumsi energi setempat, sejauh ini masih memakai energi minyak bumi berupa bensin dan solar yang harus dipasok dari lain daerah. Akibatnya subsidi yang diberikan menjadi mahal karena harga minyak bumi selalu dikonversikan dengan nilai dolar yang nilainya selalu melambung apabila dibandingkan dengan nilai rupiah.

Untuk memenuhi kebutuhan energi tersebut, perlu diupayakan sumber energi yang berasal dari daerah sendiri, diantaranya adalah energi panas bumi.

Kajian literatur menunjukkan ada mataair panas di Ie Su'um, Kecamatan Mesjid Raya, Kabupaten Aceh Besar pada aluvium dan batuan vulkanik Kuarter Tua (Plistosen).

Guna pemanfaatan energi panas bumi di sini, telah dilakukan penghitungan potensi sumberdaya (hipotesis) berdasarkan karakteristik geologi dan fluida airpanas.

\section{LOKASI}

Secara administratif daerah bahasan berada di Desa Ie Su'um, Kecamatan Masjid Raya, Kabupaten Aceh Besar, Provinsi NAD. Koordinat UTM di baratlaut pada $X=782.493 \mathrm{mT} ; Y=614300 \mathrm{mU}$, timurlaut pada $X=781940 \mathrm{mT}, Y=614250 \mathrm{mU}$, baratdaya pada $X=782.120 \mathrm{mT}, Y=613160 \mathrm{mU}$ dan di tenggara pada $X=782.660 \mathrm{mT} ; Y=613250 \mathrm{mU}$ (Gbrl).

\section{METODOLOGI}

Pekerjaan meliputi: kompilasi data sekunder, penapsiran peta geologi regional, survai lapangan, pengujian laboratoriumm serta pengolahan dan evaluasi data.

Data sekunder bersumber dari instansi Bakosurtanal (1978), Direktorat Vulkanologi (1978), Pusat Penelitian dan Pengembangan Geologi (1981), BPS dan Bappeda Kabupaten Aceh Besar (2003) dan Badan Meteorologi Dan Geofisika (2005).

Kompilasi data lapangan mengaplikasikan 2 metoda, geologi dan geokimia.

Geologi berupa pengamatan batuan, penyamplingan, analisis morfologi, stratigrafi dan struktur geologi. 
Geokimia berupa sampling airpanas, sampling tanah untuk konsentrasi $\mathrm{Hg}$ dan udara tanah untuk konsentrisi $\mathrm{CO}_{2}$ berspasi horizontal $250 \times 150 \mathrm{~m}$. Pengambilan sampel airpanas dilakukan di mataair panas Ie Su'um 1 dan 2.

Pengujian laboratorium geologi berupa petrografi batuan yang mewakili daerah, sedangkan laboratorium geokimia berupa analisis:

- Kimia airpanas untuk konsentrasi unsur $\mathrm{Na}, \mathrm{K}, \mathrm{Li}$, Cil. Fe, $\mathrm{Mg}, \mathrm{As}, \mathrm{NH}_{4}, \mathrm{HCO}_{3}, \mathrm{Cl}, \mathrm{SO}_{4}, \mathrm{~B}, \mathrm{~F}, \mathrm{SiO}_{2}$,
$\mathrm{pH}$ dan daya hantar listrik (DHL).

- Contoh tanah dengan AAS.

- Contoh udara tanah dengan cara Titrasi.

Karakteristik data dan hasil laboratorium geologi, geokimia dapat mengidentifikasi, jenis batuan, arah, kemiringan. patahan, prakiraan perangkap panas, tipe, klasifikasi airpanas, geotermometer airpanas, konsentrasi $\mathrm{Hg}$ tanah, $\mathrm{CO}_{2}$ udara tanah, daerah prospek dan potensi sumberdaya (hipotetis). 


\section{GEOLOGI}

\section{GEOLOGI UMUM}

\section{Morfologi}

Aliran sungai di P. Sumatera berawal dari puncak pegunungan Bukit Barisan di bagian barat, dengan ketinggian mencapai $>2000 \mathrm{~m} \mathrm{dpl}$. Sungai-sungai ber kemiringan curam dan mengalir mengikuti pola arah baratlaut - tenggara.

Sungai-sungai di pantai barat mengikuti arah struktur dan perlapisan batuan yang menyayat dalam, berpola mendaun (dendritik). Sedangkan di kaki bukit pantai utara polanya beragam, umumnya memotong batuan sedimen berumur Tersier Atas dan selanjutnya berpola berkelok (meander) sewaktu memasuki pesisir pantai menuju Selat Malaka. Pola aliran sungai di G. Seulawah Agam menunjukkan berpola memancar (radial).

Morfologi pantai timurlaut, berupa daerah perbukitan dengan ketinggian $<500 \mathrm{~m} \mathrm{dpl}$, diisi batuan sedimen Tersier. Morfologi pantai barat, berupa dataran tinggi dengan elevasi $+900 \mathrm{~m} \mathrm{dpl}$, diisi oleh sedimen berlapis berumur Tersier.

Deretan gunungapi berumur Plio-Plistosen dengan ketinggian antara $+500-800 \mathrm{~m}$ dpl menempati pantai utara hingga bagian barat Sigli.

Puncak tertinggi $+1810 \mathrm{~m} \mathrm{dpl}$. membentuk Kerucut G. Seulawah Agam. Terpisah dari Pegunungan Bukit Barisan terdapat dataran Banda Aceh yang amat luas, diisi oleh batuan sedimen berumur Plio-Plistosen. Selain dataran Banda Aceh terdapat juga dataran pantai yang sangat luas terletak di daerah Sigli (J.D. Bennett, dkk, 1981).

\section{Stratigrafi}

Batuan daerah Ie Su'um adalah satuan vulkanik Lam Teuba (Qtvl) berumur Plistosen. Terdiri dari: batuan gunungapi andesit-dasit, breksi batu apung, tufa, aglomerat, aliran abu di dalamnya terdapat lahar $(Q v t l)$. Batuan tersebut sebagian ditutupi aluvium (Qh) berupa kerikil, pasir dan lumpur (J.D. Bennett, dkk, 1981).

\section{Struktur}

Struktur yang mengontrol daerah adalah sesar baratlaut- tenggara (NW-SE). Pola aliran sungai di pantai barat dipengaruhi pola struktur dan litologi, yang menyayat dalam berpola mendaun.
Kegiatan tektonik telah berlangsung sejak Mesozoikum Akhir, dengan arah baratlaut-tenggara di bagian tepi cekungan/jalur gunungapi, di ujung barat paparan Sunda.

Pada Akhir Kapur di duga terjadi kegiatan tektonik di wilayah tepi cekungan. Kegiatan ini mungkin akibat adanya perubahan arah aktivitas pemekaran lempeng Indo-Australia. Aktivitas pada Akhir Kapur berlanjut hingga Tertier dan menghasilkan pengangkatan (geanticline) berbentuk jalur gunungapi Tertier. Selanjutnya kegiatan tetap berlanjut yang maksimalnya terjadi pada PlioPlistosen. Arah tektonik adalah utara barat searah jalur gunungapi Sunda (P. Jawa dan sekitarnya) dan berasosiasi dengan kegiatan subduction dari pemekaran dasar samudera Indo-Australia yang mengarah ke barat. Penunjaman miring dari plate Indo- Australia ke plate Asia terjadi akibat adanya patahan besar Sumatra yang sejajar dengan arah patahan dan berarah menganan (dextral strict-slip fault system/SFS). Arah patahan dextral ini berlanjut hingga laut Andaman di utara yang berupa cekungan (back-arc basin) yang terbentuk Awal Miosen dengan sistim patahan geser (transform - fault).

Struktur yang terdapat di daerah bahasan berupa patahan baratlaut-tenggar ( $N W-S E)$. Di G. Seulawah Agam terdapat struktur kawah dan kaldera (J.D. Bennett, dkk, 1981).

\section{GEOLOGI DAERAH}

\section{Stratigrafi}

Disusun berdasarkan hubungan relatif antara masing-masing unit. Penamaannya di dasarkan pada pusat erupsi dan genesa pembentukannya. Dari amatan batuan dan analisis petrografi, daerah dibagi menjadi 3 satuan. Urutan tua ke muda, sbb (Gbr 2):

- Satuan Diorit G. Meuh (Qpdm).

- Satuan Koluvium Ie Su'um (Qki)

- Satuan Aluvium Ie Su’um (Qai)

\section{Struktur Geologi}

Dicerminkan oleh depresi (horst dan graben), kelurusan morfologi, paset segi tiga, gawir sesar. kekar, zona breksiasi dan munculan 2 mataair panas.

Cerminan tersebut menunjukkan, terdapat sesar normal membentuk horst dan graben (depresi). Sesar Krueng Raya tersebut mengarah N $160-170^{\circ} \mathrm{E}$, dip $>75^{\circ}$. Pada graben Ie Su'um 
sejak gara di g baralt egiatan $\tan$ ini ktivitas is pada dan rbentuk $n$ tetap Plioah jalur a) dan dari yang ri plate adanya in arah rict-slip erlanjut kungan dengan

berupa eulawah a (J.D.

antara an pada

Dari 1 dibagi 2):

grabenl, $r$ sesar, panas.

-erdapat graben engarah Su'um

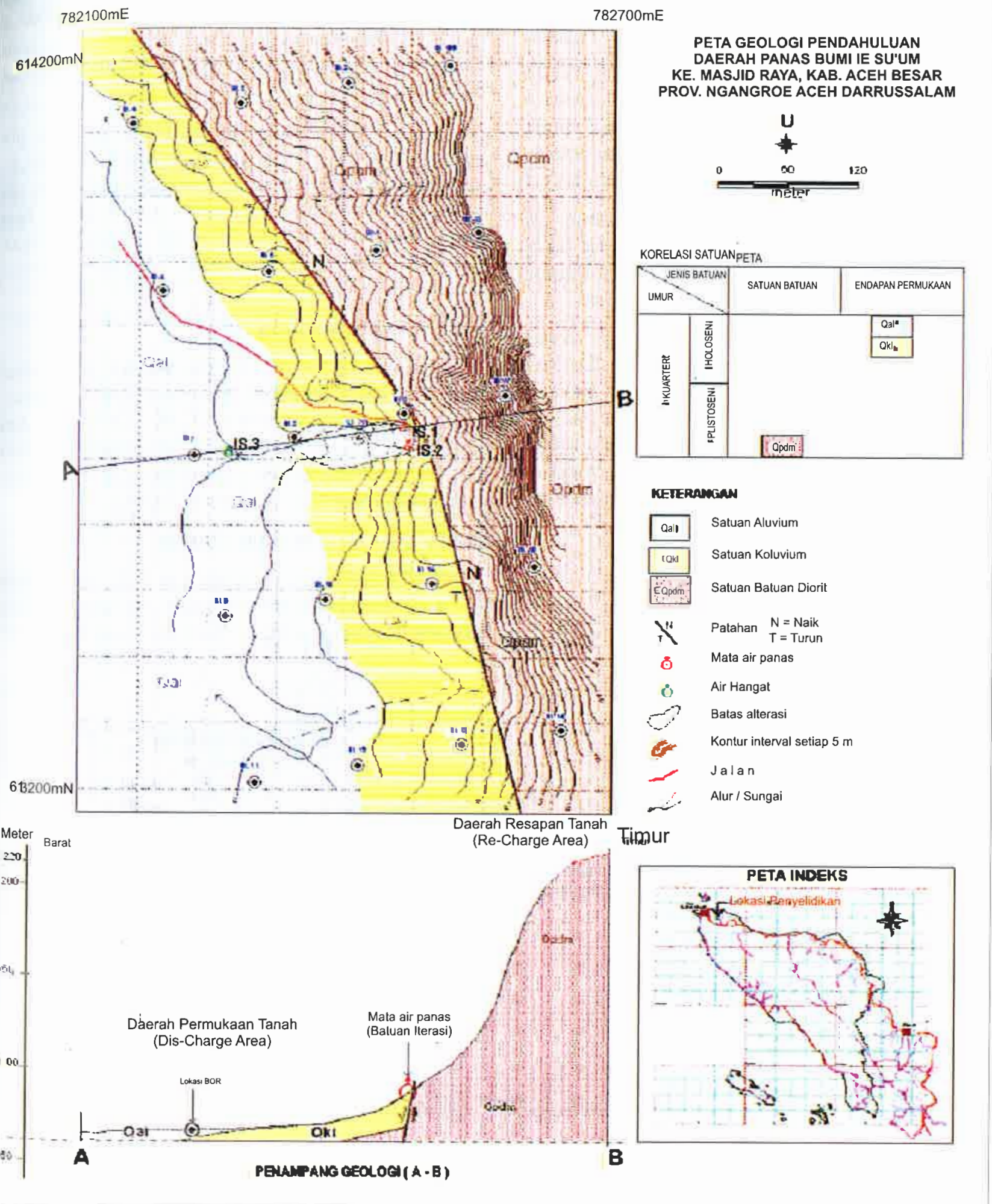

Gambar 2. Peta Geologi 


\section{Buletin Sumber Daya Geologi Volume 1 Nomor 1 - 2006}

Struktur horst berada di timur dan barat depresi.

\section{Hidrogeologi}

Wilayah airtanah dibagi 3 zona, daerah resapan air, daerah munculan air tanah dan aliran permukaan (Gbr 3).

Zona resapan air (re-charge area) berada di horst timur graben Ie Su'um, dengan elevasi mencapai + $480 \mathrm{~m} \mathrm{dpl}$.

Air hujan/ meteoric water yang turun di Perbukitan Terjal, sebagian akan meresap ke bumi pada permeabilitas batuan menjadi air tanah. Berupa kantong air (catchment area/ akumulasi) air tanah.

Daerah munculan airtanah (dis-charge area) berada di depresi Ie Su'um, seluas $\pm 50 \%$ dari luas daerah. Air yang meresap ke bumi akan muncul berupa mataair panas dan dingin di depresi Ie Su'um. Sebagiannya mengalir di muka bumi, sebagai aliran permukaan (run-off water). Aliran air permukaan berakumulasi di S. Krueng Raya dan bermuara ke Selat Malaka.

\section{GEOKIMIA}

\section{Karakter fluida}

Komposisi airpanas hasil laboratorium diuji di diagram segitiga Giggenbach $\mathrm{Cl}_{-} \mathrm{SO}_{4}-\mathrm{HC}$ $\mathrm{Na} / 1000-\mathrm{K} / 100-\sqrt{\mathrm{Mg}}$ dan B-Li-Cl. hasil menunjukkan bahwa tipe airpanasnya klorida (Gb) A), ada di lingkungan volcanic/ magmatic water, ja dari Boron. (Gbr 4 B) dan keduanya berada di part equilibrium (Gbr $4 \mathrm{C}$ ).

Karakteristik air panas Ie Su'um yang ber I netral $=7.02-7.16$ dengan suhu permukaan 86-86, $\mathrm{C}$, bertipe klorida, berada di partial equilibrium, lingkungan volcanic/ magmatic water jauh $\mathrm{d}$ : Boron. Diasumsikan ada di zona up-flow deng reservoar didominasi airpanas ("water heat (lominated).

\section{Geotermometer fluida}

Airpanas Ie Su'um merupakan tipe yang ide untuk aplikasi estimasi geotermometer airpana Berdasarkan geotermometer $\mathrm{Na} / \mathrm{K}$ Foumier da Giggenbach, suhu di kedalaman menunjukkan anta $206-228^{\circ} \mathrm{C}$. Suhu tersebut termasuk suhu reservo berentalpi sedang (intermediate entalphy).

\section{Analisis tanah dan udara tanah}

Hasil analisis $\mathrm{pH}, \mathrm{Hg}$ tanah dan $\mathrm{CO}_{2}$ udara tana di - $1 \mathrm{~m}$ menunjukkan $\mathrm{pH}$ tanah bervariasi antar 4,98-6.7. Kandungan $\mathrm{Hg}$ tanah bervariasi 20-126,6

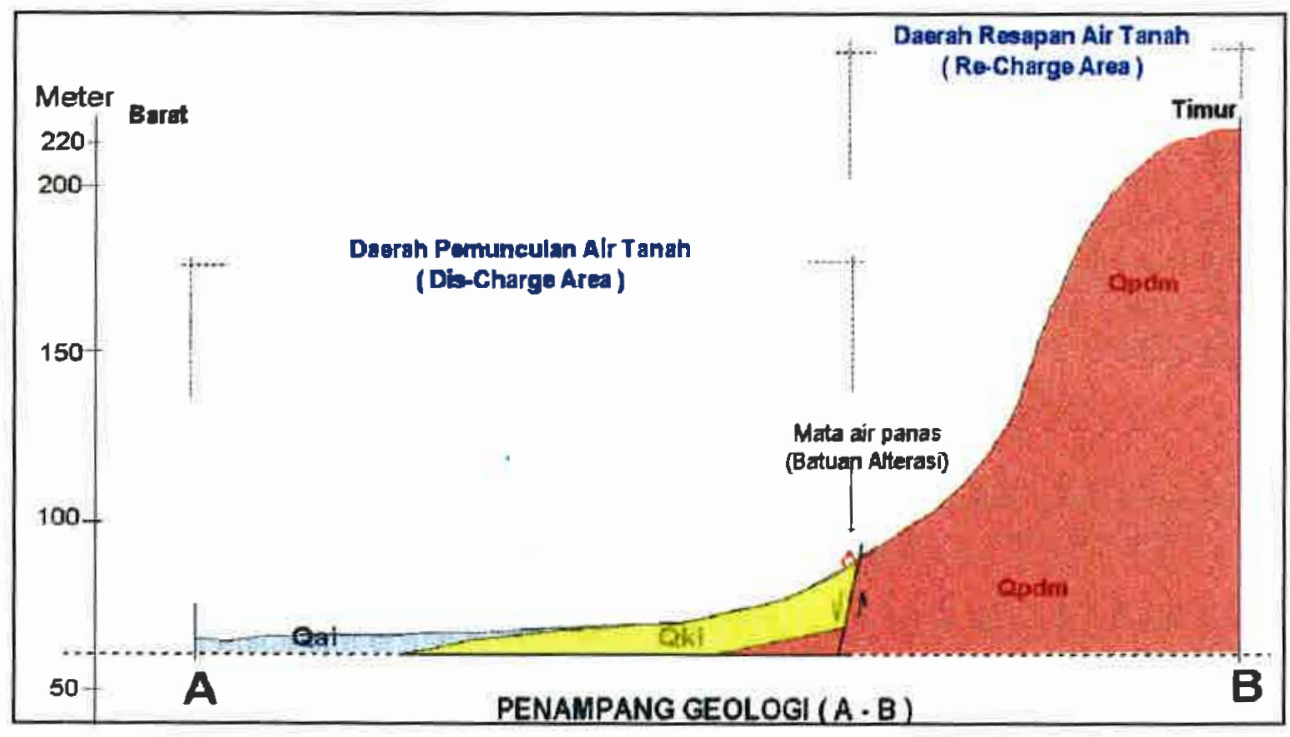

Gambar 3. Wilayah airtanah 
$-\mathrm{HCO}_{3}$

i) uji

$\left(\mathrm{Gb}^{\prime} 4\right.$

er, jauh

partial

ber $\mathrm{pH}$

$6-86,4^{\circ}$

ilum, di

ih dari

dengan

heated

g ideal iirpanas. ier dan $n$ antara eservoar

Ira tanah i antara $0-126,67$ ppb, nilai ambang batas (back-ground value) $80 \mathrm{ppb}$. Kandungan $\mathrm{CO}_{2}$ udara tanah bervariasi antara 0.3 $1,38 \%$, dan nilai ambang batas $1 \%$.

Sebaran konsentrasi $\mathrm{Hg}$ dan $\mathrm{CO}_{2}$ ( Gbr $\left.5 \mathrm{~A}, \mathrm{~B}\right)$ dan sebaran $\mathrm{pH}$ tanah dan temperatur di - $1 \mathrm{~m}$ ditampilkan di Gbr $5 \mathrm{C}$ dan D sebagai pembanding.

Anomali $\mathrm{Hg}$ berkonsentrasi $70 \mathrm{~s} / \mathrm{d}>80 \mathrm{ppb}$, berada di timurlaut. Klosur kontur 70-80 ppb terdapat di baratlaut, barat tengah dan selatan tengah (Gbr 5 A).

Anomali $\mathrm{CO}_{2}$ dengan konsentrasi 0.8 hingga $>1$ $\%$ ada di timurlaut dan klosur kontur nilai sama ada di tenggara tengah (Gbr $5 \mathrm{~B}$ ).
Kecenderungan yang sama terjadi pada sebaran $\mathrm{pH}$ tanah rendah dan pola sebaran suhu udara tanah nilai tinggi di kedalaman - $1 \mathrm{~m}$ ( $\mathrm{Gbr} 5 \mathrm{C}$ dan $\mathrm{D})$.

Anomali $\mathrm{Hg}$ tanah, $\mathrm{CO}_{2}$ udara tanah, $\mathrm{pH}$ tanah rendah dan suhu udara tanah tinggi di kedalaman - 1 $\mathrm{m}$ menunjukkan arah utara baratlaut-selatan tenggara, searah sesar Krueng Raya (N 160-170 $\mathrm{E}$ ). Pola tersebut mencerminkan fluida yang naik kepermukaan dan terperangkap oleh soil di - $1 \mathrm{~m}$ (horizon B).

Berdasarkan pola konsentrasi $\mathrm{Hg}$ tanah dan $\mathrm{CO}_{2}$ udara tanah tinggi dan struktur geologi, luas daerah prospek Ie Su'um di asumsikan $\pm 0,5 \mathrm{~km}^{2}$ (Gbr 6).

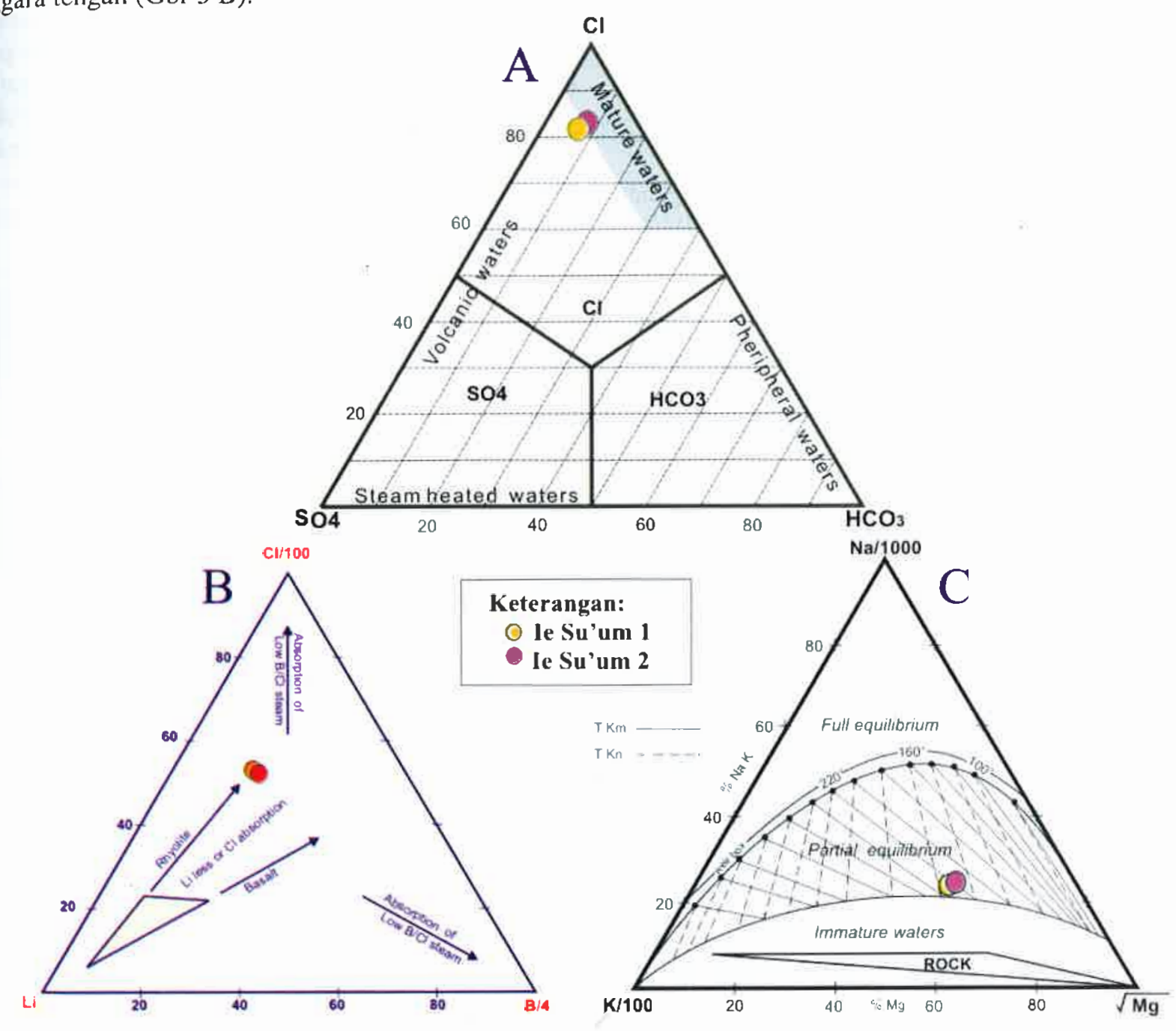

Gambar 4

Pengujian fluida terhadap Diagram Segitiga Cl-SO $-\mathrm{SCO}_{3}$ (gambar A), Pengujian fluida terhadap Diagram Segitiga Cl/100-B/4-Li (gambar B) dan Pengujian fluida terhadap Diagram Segitiga $\mathrm{Na} / 1000-\mathrm{K} / 100-\sqrt{\mathrm{Mg}}$ (gambar C) 


\section{POTENSI}

Daerah prospek berada di barat patahan Krueng Raya, bersistim up-flow seluas $\pm 0,5 \mathrm{~km}^{2}$. Berdasarkan standard Estimasi Potensi Panas Bumi menunjukkan bahwa Sumberdaya (hipotetis) Ie Su'um adalah \pm 13 Mwe.

\section{DISKUSI}

Berdasarkan karakter fisika dan kimia air panas disimpulkan bahwa fluida berada di zona "up-flow". Artinya berasal langsung dari dalam (deep water) dan reservoarnya didominasi airpanas (water heated dominated') bersuhu antara 206-228 C. Reservoir itu termasuk suhu reservoar berentalpi sedang (intermediate entalphy).

Potensi Sumberdaya (hipotetis) adalah \pm 13 Mwe, dengan mengaplikasikan suhu geotermometer $228^{\circ} \mathrm{C}$

Pemanfaatannya bisa dipakai secara langsung (direct-used ) dan tidak langsung (indirect - used).
Pemanfaatan tidak langsung adalah untuk listrik. Dalam prosesnya perlu mengekstrasi energi panas dari fluida menjadi energi listrik

Pemanfaatan langsung diantaranya untuk: pemanasan rumah kaca, budidaya pertanian (pengering kopi, kopra, kemiri, coklat, teh) dan budidaya ikan/ perikanan (pengering ikan laut atau ikan asin dan udang). Juga dapat dimanfaatkan untuk pariwisata (hotel, pemandian/kolam renang air panas, SPA dan pengobatan kesehatan lainnya (curing).

\section{REKOMENDASI}

Di daerah Ie Su'um - Masjid Raya, Kabupaten Besar perlu ditindak lanjuti dengan kajian terpadu geologi, geokimia dan geofisika untuk mendapatkan potensi cadangan, konfigurasi batuan dan struktur bawah permukaan, serta rekonstruksi model panas bumi. Sebagai landasan penentuan titik pemboran LS (gradient thermal) dan pemboran eksplorasi untuk memanfaatkan fluida panas melalui lubang sumur.

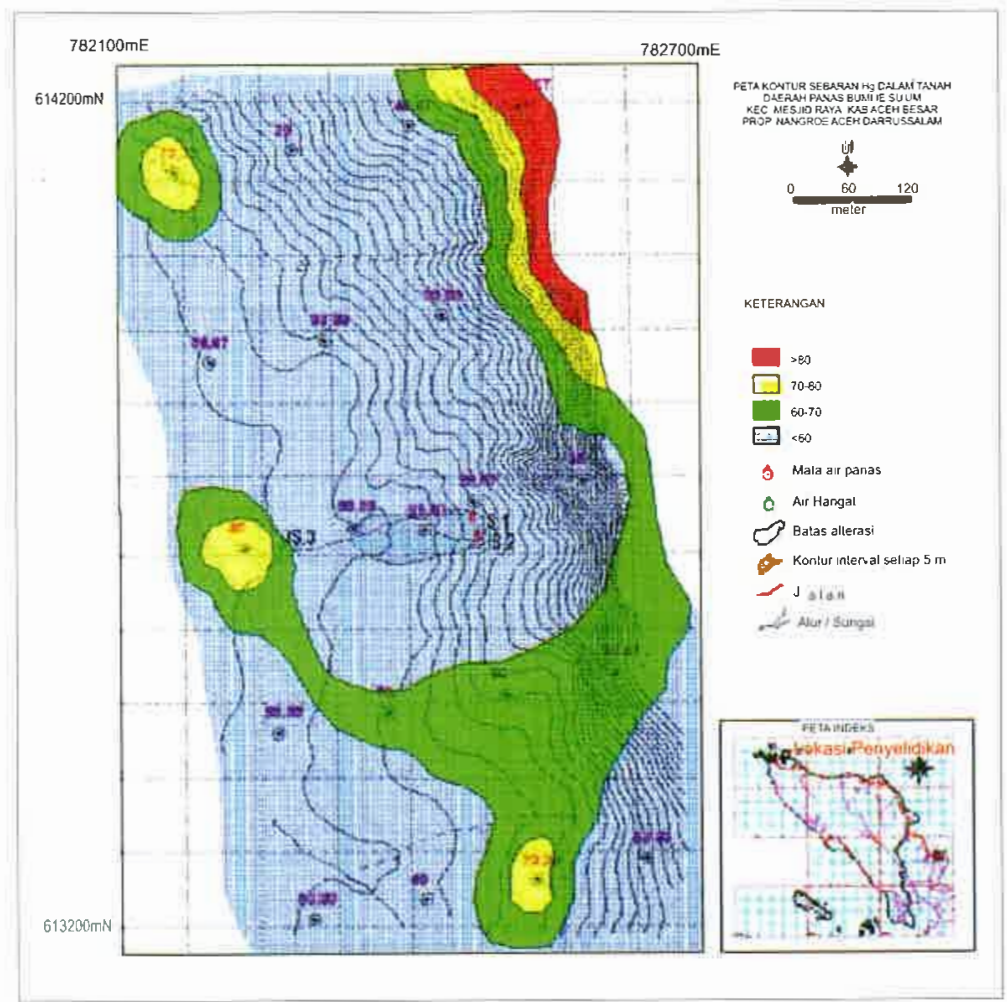

Gambar 5 A. Peta anomali $\mathrm{Hg}$ tanah 
listrik. las dari untuk: rtanian h) dan ut atau untuk panas, oupaten terpadu apatkan itruktur panas ran LS untuk iur.

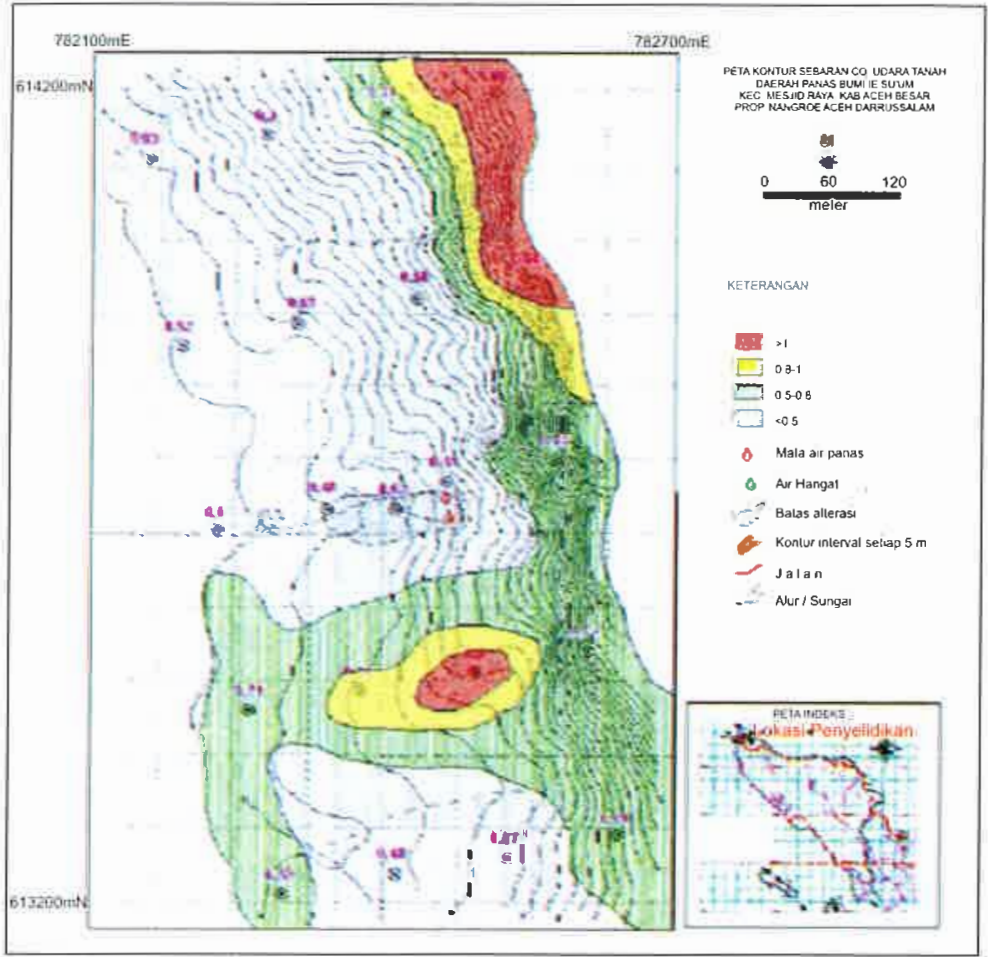

Gambar 5 B. Peta anomali $\mathrm{CO}_{2}$ udara tanah

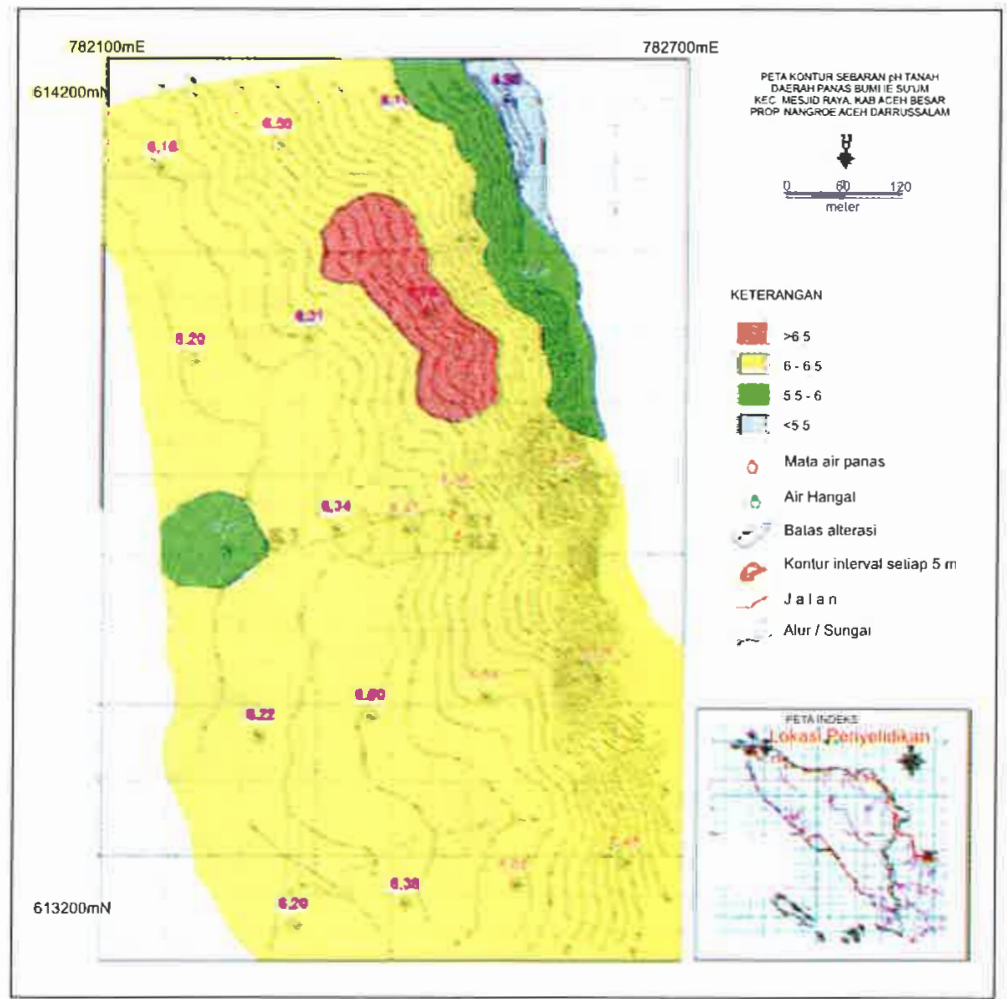

Gambar 5 C. Peta sebaran $\mathrm{pH}$ tanah 


\section{Buletin Sumber Daya Geologi Volume 1 Nomor 1 - 2006}

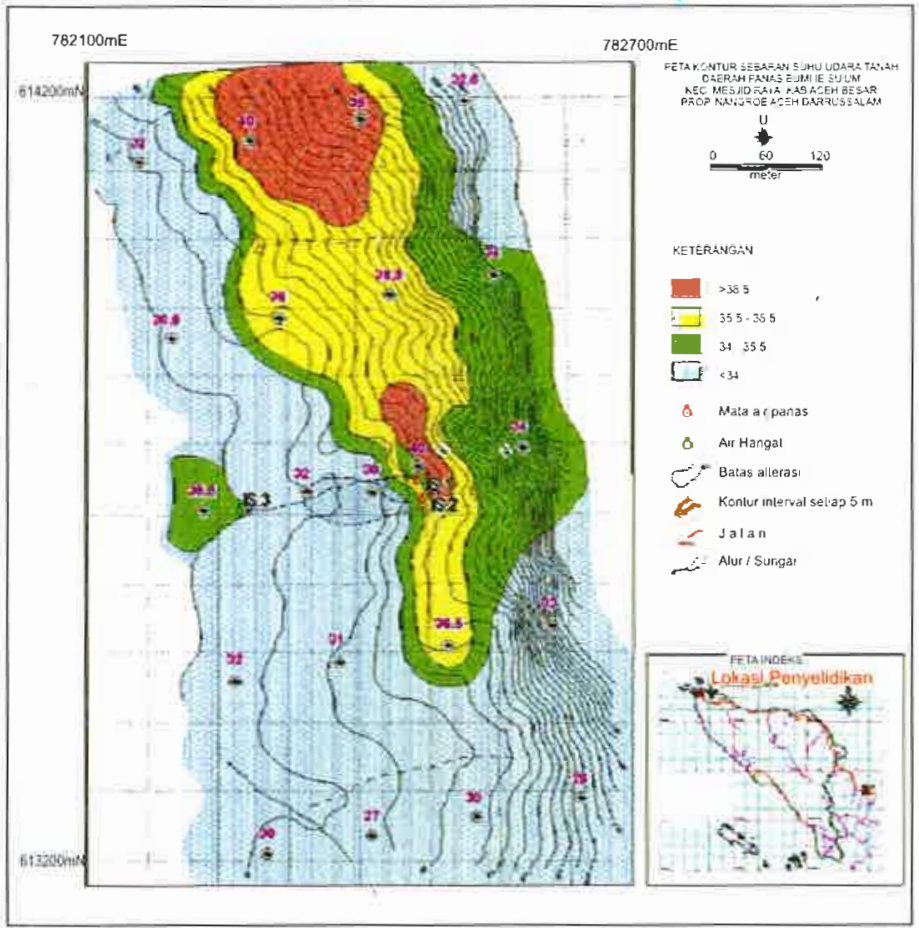

Gambar 5 D. Peta sebaran suhu udara tanah

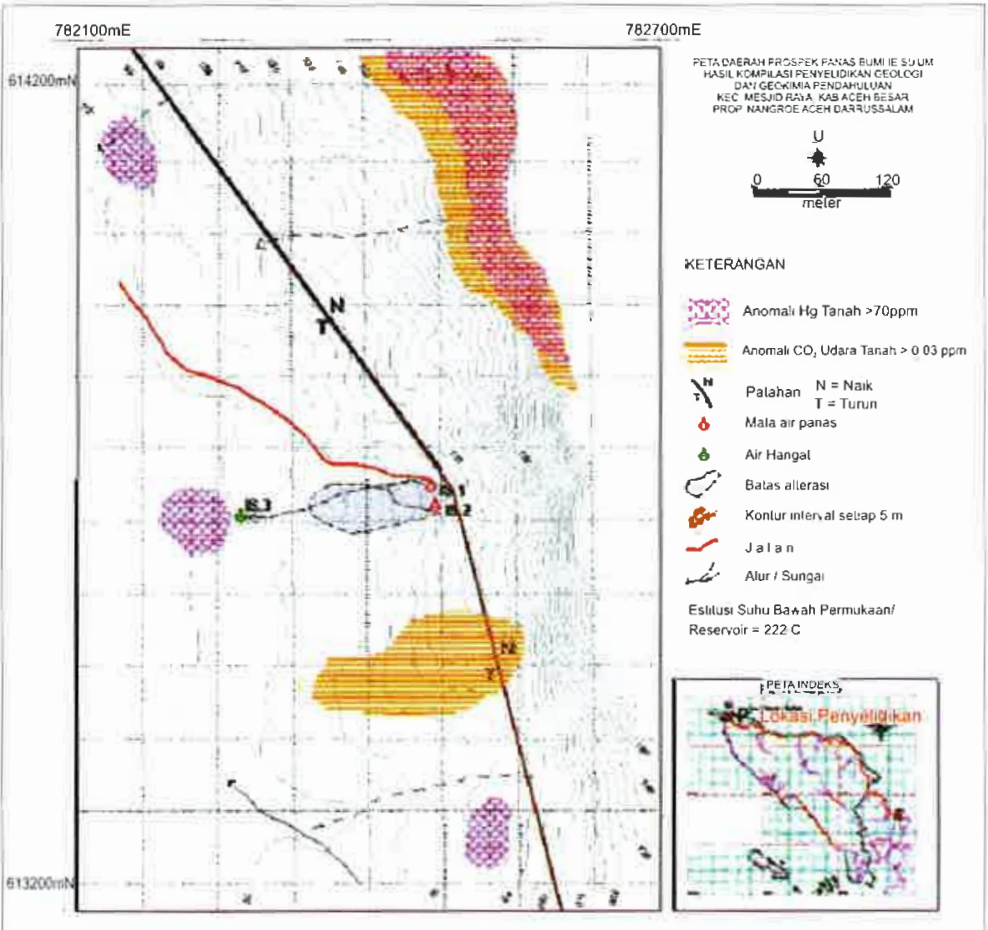

Gambar 6. Daerah prospek berdasar anomali $\mathrm{Hg}$ tanah, $\mathrm{CO}_{2}$ udara tanah dan patahan geologi 


\section{PUSTAKA}

Bakosurtanal, 1978, Peta Rupa Bumi Indonesia, Skala I:50.000. Lembar 0421-61, Zone UTM 46 U.

BMG, 2004; Data curah hujan Indonesia 2004

Bemmelen, van R.W., 1949. The Geology of Indonesia. Vol. I A. General Geology Of Indonesia And Adjacent Archipelagoes. Government Printing Office. The Hague. Netherlands.

Bennett, J.D., dkk (1981), Peta Geologi Lembar Banda Aceh, Sumatra, skala 1: 250.000.

BPS 2004; Aceh Besar Dalam Angka 2003, Kerjasama BPS dan Bappeda Kabupaten Aceh Besar.

Fournier, R.O., 1981. Application of Water Geochemistry Geothermal Exploration and Reservoir Engineering, "Geothermal System: Principles and Case Histories". John Willey \& Sons. New York.

Giggenbach, W.F., 1988. Geothermal Solute Equilibria Deviation of Na-K-Mg-Ca Geo- Indicators. Geochemica Acta 52. pp. $2749-2765$.

Lawless, J., 1995. Guidebook: An Introduction to Geothermal System. Short course. Unocal Ltd. Jakarta.

Mahon K., Ellis, A.J., 1977. Chemistry and Geothermal System. Academic Press Inc. Orlando.

Nasution, A, dkk, 1978: Penyelidikan Inventarisasi Gejala Panas Bumi Daerah Seulawah Agam, Kabupaten Aceh Besar, Daerah Istimewa Aceh.

Pertamina UEP Sumbagut Eksplorasi P. Brandan, 1994, Peta Geologi G. Selawah Agam Skala 1: 25.000. 